\title{
Selection of Lactic Acid Bacteria as Probiotic Candidate for Chicken
}

\author{
F. Hamida ${ }^{a}$, K. G. Wiryawan ${ }^{\text {b,d }}$, \& A. Meryandini ${ }^{c, d}, *$ \\ a Postgraduate of Microbiology Study Program, Department of Biology, Faculty of Mathematics and Natural Science, \\ Bogor Agricultural University \\ ${ }^{b}$ Department of Nutrition and Feed Technology, Faculty of Animal Science, \\ Bogor Agricultural University \\ 'Department of Biology, Faculty of Mathematics and Natural Science, Bogor Agricultural University \\ ${ }^{\mathrm{d}}$ Research Center of Bioresources and Biotechnology (PPSHB), Bogor Agricultural University \\ Jalan Agatis, Kampus IPB Darmaga Bogor 16680, Indonesia \\ (Received 22-04-2015; Reviewed 12-05-2015; Accepted 31-07-2015)
}

\begin{abstract}
Lactic acid bacteria (LAB) regarded as safe microorganisms; they can naturally live in gastrointestinal tract, so appropriately used as a probiotic for chicken. This study aimed to select six isolates of $\mathrm{LAB}(\mathrm{E} 1223, \mathrm{E} 3, \mathrm{E4}, \mathrm{E5}, \mathrm{E7}$, and E8) to obtain the isolates potentially as probiotic candidate for chicken. The six isolates were derived from spontaneous fermented corn obtained from Laboratory of Animal Biotechnology and Biomedical, PPSHB, Bogor Agricultural University, Indonesia. LAB isolates were tested their susceptibility to antibiotics (bambermycin, erythromycin, chloramphenicol, and tetracycline) then were examined in vitro for their tolerance to gastrointestinal $\mathrm{pH}(2,3,4$, and 7.2$)$ and $0.5 \%$ bile salt condition, antimicrobial activity against Salmonella enteritidis and Enterococcus casseliflavus, and ability to adhere to chicken ileal cells. The results showed the isolates E5, E7, and E8 were sensitive to tetracycline and chloramphenicol, they could survive at $\mathrm{pH} 2,3,4$, and 7.2 , could survive at $0.5 \%$ bile salts, produced antimicrobial activity, and able to adhere to ileal cells $\left(9.40 \pm 0.00 \mathrm{Log} \mathrm{CFU} / \mathrm{cm}^{2}\right.$ of E8) and were significantly $(\mathrm{P}<0.05)$ higher than those of control $\left(5.30 \pm 0.14 \mathrm{Log} \mathrm{CFU} / \mathrm{cm}^{2}\right)$. In conclusion, this study showed that isolate E8 had better potential compared to isolates E5 and E7 in most in vitro assays as a probiotic candidate for chicken. E5, E7, and E8 were closely related with Pediococcus pentosaceus based on 16S rRNA gene.
\end{abstract}

Key words: LAB, probiotic, chicken, in vitro

\section{ABSTRAK}

Bakteri asam laktat (BAL) dianggap sebagai mikroorganisme aman, dapat hidup di dalam saluran pencernaan, sehingga tepat digunakan sebagai mikroorganisme probiotik untuk ayam. Penelitian ini bertujuan menyeleksi secara in vitro enam isolat BAL (E1223, E3, E4, E5, E7, E8) untuk memperoleh BAL berpotensi sebagai kandidat probiotik ayam. Enam isolat berasal dari jagung fermentasi yang diperoleh dari Laboratorium Bioteknologi Hewan dan Biomedis, PPSHB, Institut Pertanian Bogor, Indonesia. Isolat BAL diuji sensitifitasnya terhadap antibiotik (bambermisin, eritromisin, kloramfenikol, dan tetrasiklin) lalu diuji secara in vitro ketahanannya terhadap $\mathrm{pH}$ saluran pencernaan (2; 3; 4; dan 7,2) dan 0,5\% garam empedu, aktivitas antimikroba terhadap Salmonella enteritidis dan Enterococcus casseliflavus, dan kemampuan menempel pada ileum ayam. Hasil penelitian menunjukkan bahwa isolat E5, E7, dan E8 sensitif terhadap tetrasiklin dan kloramfenikol, toleran pada pH pencernaan dan garam empedu, menghasilkan aktivitas antimikrob, dan mampu menempel pada ileum ayam (sel isolat E8 yang menempel sebesar 9,40 $\left.\pm 0,00 \mathrm{Log} C F U / \mathrm{cm}^{2}\right)$ signifikan $(\mathrm{P}<0,05)$ lebih tinggi dibandingkan dengan kontrol $\left(5,30 \pm 0,14 \mathrm{Log} \mathrm{CFU} / \mathrm{cm}^{2}\right)$. Kesimpulan penelitian ini menunjukkan bahwa isolat E8 memiliki potensi lebih baik daripada isolat E5 dan E7 di sebagian besar uji in vitro sebagai kandidat probiotik ayam. Isolat E5, E7, dan E8 memiliki homologi 99\% dengan Pediococcus pentosaceus berdasarkan gen $16 \mathrm{~S}$ rRNA.

Kata kunci: BAL, probiotik, ayam, in vitro

*Corresponding author:

E-mail: ameryandini@yahoo.com 


\section{INTRODUCTION}

Antibiotic growth promoters (AGPs) as feed additives have been used since 1940s to improve livestock productivity and disease prevention (Castanon, 2007). The excessive and continuous use of antibiotics can lead to antibiotic residues accumulation (Tao et al., 2012) and resistance of pathogenic bacteria (Vignaroli et al., 2011). Antibiotics use as feed additives has been restricted gradually since 1970s in Europe (Castanon, 2007). In Indonesia, a ban of the use of antibiotics as feed additives has been regulated in Law of the Ministry of Agriculture No. 18 in year 2009 of Article 22 Paragraph 4c about Animal Husbandry and Animal Health (Kementan, 2009). Screening of alternative materials as feed additives has been done by previous researchers using enzymes, probiotics, herbal plants, and organic acids (Huyghebaert et al., 2011; Gunal et al., 2006; Wiryawan et al., 2005).

Probiotics as live microorganisms which when administered in adequate amounts confer a health benefit to the host (FAO/WHO, 2002). LAB microorganisms are often used as probiotics and could be isolated from the digestive tract, fermentation of milk, and grain crops (Jannah et al., 2014; Rosyidah et al., 2013; Bao et al., 2010). Jannah et al. (2014) and Gunal et al. (2006) reported that interaction of $\mathrm{LAB}$ with intestine could reduce the population of intestinal pathogens. According to FAO/ WHO (2002) probiotics as feed additives should have minimum criteria as probiotics to exert their beneficial effect to the host: 1). Probiotic strains should identified as having phenotypic and genotypic specifications of characteristics, 2). In in vitro assays, probiotic strains should be able to survive in stomach acid, bile salts, adhere to the mucus or intestinal epithelial cells, able to produce antimicrobial activity, 3). Do not produce toxins, not resistant to antibiotics, and are not pathogenic bacteria (EFSA 2012). Exploration of LAB strains as probiotic has been carried out in previous studies by isolation and screening using in vitro methods (Babot et al., 2014; Jannah et. al., 2014; Lee et al., 2014). In vitro assays are very important to assess the safety of probiotic strains, beside that the in vitro data can be information about the advantages of strains as a probiotic candidate (FAO/WHO, 2002). This study aimed to select six isolates of LAB (E1223, E3, E4, E5, E7, and E8) derived from spontaneous fermented corn (Rosyidah et al., 2013) to obtain the isolates potentially as probiotic candidate for chicken. Selection of candidate probiotic was derived from the fermented corn that may facilitate the initial selection to obtain isolates which are not resistant to antibiotics.

\section{MATERIALS AND METHODS}

\section{Microorganisms and Culture Conditions}

Six LAB isolates (E1223, E3, E4, E5, E7, and E8) used in the present study were derived from spontaneous fermented corn that were obtained from Laboratory of Animal Biotechnology and Biomedical, PPSHB, Bogor Agricultural University, Indonesia. Pathogenic bacteria indicator (Salmonella enteritidis and Enterococcus casseliflavus) were obtained from Laboratory of Animal Diseases and Veterinary Public Health, Faculty of Veterinary Biomedicine, Bogor Agricultural University, Indonesia. LAB isolates and E. casseliflavus were grown and propagated in MRS broth (Himedia) and incubated in anaerobic jar incubator with GasPak (Merck, Germany) at $37^{\circ} \mathrm{C}$. $S$. enteritidis was grown and propagated in Nutrient Broth (Difco) in shaker incubator at $37^{\circ} \mathrm{C}$.

\section{Susceptibility to Antibiotics}

Antibiotics susceptibility assay were performed according to the method described by Babot et al. (2014) and modified by well diffusion agar method. Culture of $14 \mathrm{~h}$ of LAB isolates was poured $\left(10^{8}-10^{9} \mathrm{CFU} / \mathrm{mL}\right)$ into MRS agar plate. The wells were made by sterilized pipette tip with diameter size of $7 \mathrm{~mm}$. Respectively, each well was filled with $50 \mu \mathrm{L}$ antibiotics test $(25$ ppm bambermycin, $15 \mu \mathrm{g}$ erythromycin, $30 \mu \mathrm{g}$ tetracycline, and $30 \mu \mathrm{g}$ chloramphenicol). Agar plates were incubated for $24 \mathrm{~h}$ at $37^{\circ} \mathrm{C}$. The diameter of inhibition zone was measured by rule $(\mathrm{mm})$. The susceptibility of isolates was classified as sensitive, intermediate, and resistant according to the interpretative standards described by Walker (2006) and Swenson et al. (1990). The sensitive isolates or not resistant to antibiotics tested were selected as candidate to be tested in subsequent assays.

\section{Tolerance to Gastrointestinal pH and Bile Salt}

Acid and bile tolerance assays were performed according to the method described by Messaoudi et al. (2012) and Bao et al. 2010. Culture of $14 \mathrm{~h}$ of LAB isolates were inoculated $\left(10^{8}-10^{9} \mathrm{CFU} / \mathrm{mL}\right)$ into MRS broth (adjusted to $\mathrm{pH} \mathrm{2,3,4,} \mathrm{and} 7.2$ with $\mathrm{HCl} 1 \mathrm{~N}$ and $\mathrm{NaOH}$ $1 \mathrm{~N}$ ) and incubated for $3 \mathrm{~h}$ at $37^{\circ} \mathrm{C}$. Beside that, bile salt tolerance assay was conducted by using MRS broth containing $0.5 \% \mathrm{w} / \mathrm{v}$ bile salt (Himedia) and incubated for 5 h $37^{\circ} \mathrm{C}$. The viable cell was enumerated by total plate count method using MRS agar plates. The parameter of survival ability was determined by calculating the decrease in cell viability after treatment ( $\log \mathrm{CFU} / \mathrm{mL}$ ) and survival rate $(\%)$. The decrease in cell viability was determined by calculating:

$$
\log _{\text {before treatment }} \mathrm{CFU} / \mathrm{mL}-\log _{\text {after treatment }} \mathrm{CFU} / \mathrm{mL}
$$

Survival rate (\%) was calculated according to the following equation:

$\left(\log _{\text {after treatment }} \mathrm{CFU} \mathrm{mL} \mathrm{m}^{-1} / \log _{\text {before treatment }} \mathrm{CFU} \mathrm{mL} \mathrm{mL}^{-1}\right) \times 100 \%$

\section{Antimicrobial Activity of LAB Isolates}

Antimicrobial activity was analyzed by using well diffusion agar method described by Klose et al. (2010). Cell-free supernatant of LAB isolates were obtained from overnight culture centrifugation (IEC Clinical Centrifuge 215, US) at $7000 \mathrm{rpm}$ for $10 \mathrm{~min}$. Supernatants were divided into 3 portions: 1) untreatment supernatant ( $\mathrm{pH} \pm 4.36$ ) as positive control; 2) neutralized supernatant with $1 \mathrm{~N} \mathrm{NaOH}(\mathrm{pH}$ 6.5) to evaluate organic acid activity; 3 ) neutralized supernatant ( $\mathrm{pH} 6.5)$ 
that was added with $1 \mathrm{mg} / \mathrm{mL}$ K-Proteinase (Nacalai Tesque, Inc.) to evaluate bacteriocin-like inhibitory substances activity, the mixture was incubated for $2 \mathrm{~h}$ at 30 ${ }^{\circ} \mathrm{C}$. Enzymatic proteinase activities were inactivated by incubation at $100{ }^{\circ} \mathrm{C}$ for $5 \mathrm{~min}$. All of the supernatants were sterilized by membrane filter with pore size 0.22 $\mu \mathrm{m}$. Indicator bacteria S. enteritidis and E. casseliflavus (were cultured overnight with concentration $10^{7}-10^{8}$ $\mathrm{CFU} / \mathrm{mL}$ ) were poured into Nutrient agar plates. The wells were made by sterilized pipette tip diameter 7 $\mathrm{mm}$. Each supernatant $(50 \mu \mathrm{L})$ was placed into different wells and assayed for inhibitory effects on agar plates. The plates were incubated for $24 \mathrm{~h}$ at $37^{\circ} \mathrm{C}$. The diameter of zone inhibition was measured by rule $(\mathrm{mm})$.

\section{In Vitro Ability of LAB to Adhere to Chicken Ileal Cell Assay}

The method described by Mayra-Makinen et al. (1983) was used for the preparation of the intestinal cells. Segment of ileum from broiler were cut by $1 \times 1$ $\mathrm{cm}^{2}$ size. The ileum was opened and washed twice with sterilized phosphate-buffer saline (PBS pH 7.2). Respectively, each piece of ileum tissue was held in PBS at $4{ }^{\circ} \mathrm{C}$ for $30 \mathrm{~min}$ to remove the surface mucus and then washed three times with PBS. The overnight broth culture of LAB were centrifuged at $7000 \mathrm{rpm}$ for $10 \mathrm{~min}$ and resuspended in PBS. The suspension of LAB contained $\pm 10^{8} \mathrm{sel} / \mathrm{mL}$. An ileal cell held in LAB suspension was incubated for $30 \mathrm{~min}$ at $37^{\circ} \mathrm{C}$. Meanwhile, the same preparation was performed without cell of LAB as control. After incubation, ileal cell was washed three times in PBS, extracted in $1 \mathrm{~mL}$ PBS, and vortexed with high speed for 2 min to obtain adhesive bacterial cells. Bacterial adherence was assessed by enumeration of the numbers of bacterial cell (from ileum extraction) on GYP $+0.5 \% \mathrm{CaCO}_{3}$ agar plates. Agar plates were incubated for $24 \mathrm{~h}$ at $37^{\circ} \mathrm{C}$. The adhesion (\%) was calculated according to the following equation:

$\left(\log _{\mathrm{N} 1}\right.$ CFU cm ${ }^{-2} / \log _{\mathrm{N} 0}$ CFU cm $\left.{ }^{-2}\right) \times 100 \%$

$\mathrm{N} 0=$ cell numbers before treatment, $\mathrm{N} 1=$ cell numbers from ileum extraction after $30 \mathrm{~min}$ incubation.

\section{Molecular Identification of $16 S$ rRNA Gene of LAB Isolates}

The early stage for molecular identification of $16 S$ rRNA gene is isolation of genomic DNAs. Isolation of genomic DNAs of LAB isolates was done by using Genomic DNA Mini Kit Blood/Cultured Cell (Geneaid) according to the manufacturer's protocol. The DNAs isolate from each LAB isolate were prepared for PCR reaction mixture. A PCR reaction mixture for each sample consisted of $20 \mu \mathrm{L}$ GoTaq Green Master Mix (Promega, USA), $2.5 \mu \mathrm{L}$ of each primer (10 pmol), $10 \mu \mathrm{L}$ nuclease free water, and $5 \mu \mathrm{L}$ DNA template. The amplification reaction with forward primer 63F (5'-CAG GCC TAA CAC ATG CAA GTC-3') and reverse primer 1387R (5'GGG CGG WGT GTA CAA GGC-3') (Marchesi et al., 1998) using an Applied Biosystems Thermal Cycler 2720 (Life Tech). The temperature gradient of PCR reaction was set up at $94{ }^{\circ} \mathrm{C}$ for $5 \mathrm{~min}$ (an initial denaturation), 94 ${ }^{\circ} \mathrm{C}$ for $30 \mathrm{~s}$ (denaturation), $55^{\circ} \mathrm{C}$ for $45 \mathrm{~s}$ (annealing), 72 ${ }^{\circ} \mathrm{C}$ for $1 \mathrm{~min}$ (elongation), these reaction (denaturation, annealing and elongation) were followed by 30 cycles, and then final elongation at $72{ }^{\circ} \mathrm{C}$ for $7 \mathrm{~min}$. PCR products of each sample were confirmed by running an electrophoresis using 1\% agarose gel in 1x TAE buffer for $\pm 45 \mathrm{~min}$ on constanta $80 \mathrm{~V}$ and $33 \mathrm{~mA}$. The DNA bands formed from electrophoresis process was visualized on UV transluminator with ethidium bromide staining. The sequencing of genomic DNAs was conducted by sending the PCR products to a company providing sequences services. The DNA sequences were compared with other data sequences $16 \mathrm{~S}$ rRNA gene in GenBank applied by using the BLASTN tools through the NCBI. The alignment of sequences used Clustal $X$ program and was edited by MEGA 5.05 program. The construction of phylogenetic tree used neighbor-joining method by 1000 $x$ bootstrap in MEGA 5.05 program (Felsenstein, 1985).

\section{Statistical Analysis}

All research data (except data of susceptibility to antibiotic and molecular identification) were shown as the mean \pm standard deviation of three replicates of treatment. All quantitative data were calculated to ANOVA analysis by using IBM SPSS statistics 21.0. Duncan test was conducted as a further test to identify statistically significant differences in the experiment $(\alpha=$ $0.05)$.

\section{RESULTS AND DISCUSSION}

\section{Susceptibility to Antibiotics}

Susceptibility of LAB isolates to antibiotics showed variations in results (Table 1). All isolates were resistant to bambermycin. Previous study by Jeong et al. (2009) reported that most species of $\mathrm{LAB}$ were found resistant to bambermycin and it was considered as an intrinsically resistant. The LAB intrinsically resistant allowed its use as probiotic (EFSA, 2012). Intrinsically resistant was caused by several natural physiological factors and non-transmissible (Pfaller, 2006). E3 isolate was resistant to erythromycin, chloramphenicol, and tetracycline. Similarly, E4 and E1223 isolates were resistant to erythromycin and tetracycline but intermediate to chloramphenicol. Thumu \& Halami (2012) and Nawaz et al. (2011) reported that many LAB resistant to erythromycin, tetracycline, and chloramphenicol related to the presence of gene encoding resistant due to mutation or mobile genes. In contrast, Klare et al. (2007) reported that gram-positive bacteria are generally sensitive to antibiotics that inhibit the protein synthesis such as erythromycin and chloramphenicol. Isolates of E5, E7, and E8 did not resistant to erythromycin, chloramphenicol, and tetracycline. Some species of LAB showed phenotypical sensitive to tetracycline and chloramphenicol, then intermediate to erythromycin but the gene encoding of erythromycin resistance was not found (Ouoba et al., 2008). According to FAO/WHO (2002) and EFSA (2012) probiotics as feed additives should not resistant to anti- 


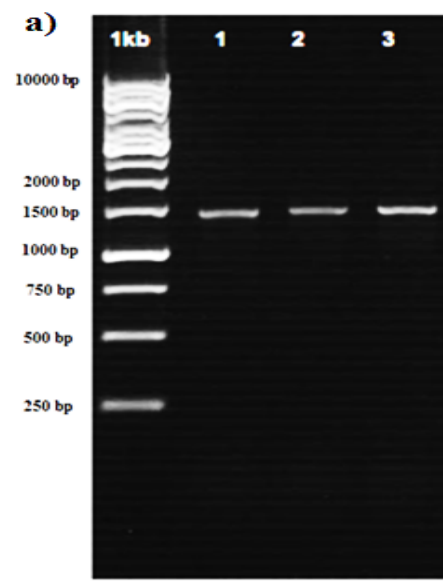

b)

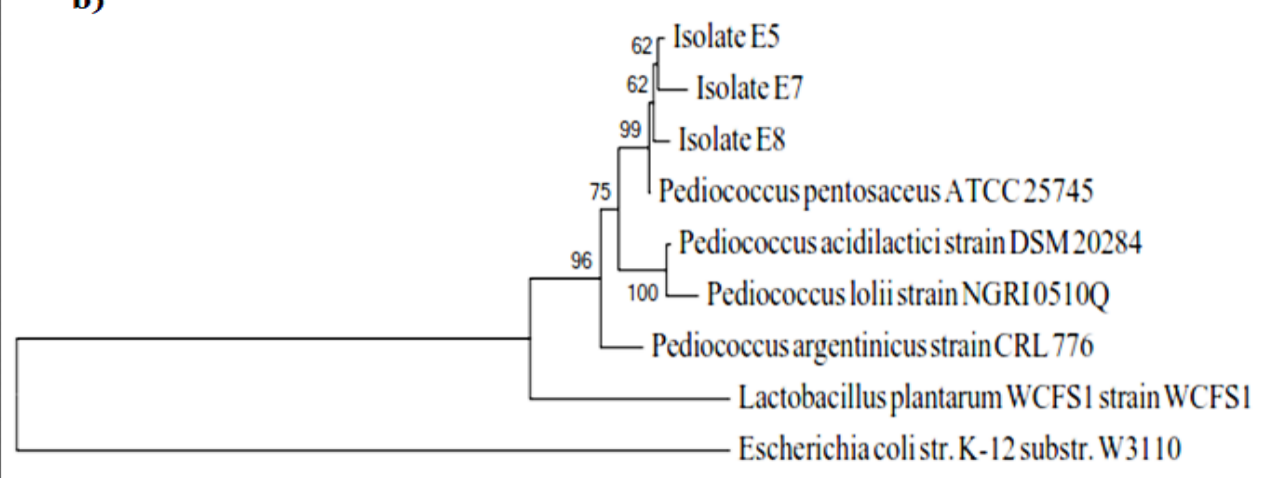

Figure 1. a)Visualization electrophoresis 1\% Agarose gel of PCR product 16S rRNA gene isolates BAL (1 kb: Marker 1 kb, well 1: E5 isolate, well 2: E7 isolate, well 3: E8 isolate. b) Phylogenetic analysis of the 16S rRNA gene of the LAB isolate compared with database of 16S rRNA gene in GenBank NCBI using Neighbor-joining method with 1000x boostrap.

Table 1. Susceptibility of LAB isolates to antibiotics on MRS agar for $24 \mathrm{~h}$

\begin{tabular}{ccccc}
\hline \multirow{2}{*}{ LAB isolates } & \multicolumn{4}{c}{ Interpretation of LAB to antibiotics } \\
\cline { 2 - 5 } & $\begin{array}{c}\text { Bambermycin } \\
20 \mathrm{ppm}\end{array}$ & $\begin{array}{c}\text { Erithromycin } \\
15 \mu \mathrm{g}\end{array}$ & $\begin{array}{c}\text { Chloramphenicol } \\
30 \mu \mathrm{g}\end{array}$ & $\begin{array}{c}\text { Tetracycline } \\
30 \mu \mathrm{g}\end{array}$ \\
\hline E1223 & {$[\mathrm{R}]$} & {$[\mathrm{R}]$} & {$[\mathrm{I}]$} & {$[\mathrm{R}]$} \\
E3 & {$[\mathrm{R}]$} & {$[\mathrm{R}]$} & {$[\mathrm{R}]$} & {$[\mathrm{R}]$} \\
E4 & {$[\mathrm{R}]$} & {$[\mathrm{R}]$} & {$[\mathrm{I}]$} & {$[\mathrm{R}]$} \\
E5 & {$[\mathrm{R}]$} & {$[\mathrm{I}]$} & {$[\mathrm{S}]$} & {$[\mathrm{S}]$} \\
E7 & {$[\mathrm{R}]$} & {$[\mathrm{S}]$} & {$[\mathrm{S}]$} & {$[\mathrm{S}]$} \\
E8 & {$[\mathrm{R}]$} & {$[\mathrm{I}]$} & {$[\mathrm{S}]$} & {$[\mathrm{S}]$} \\
\hline
\end{tabular}

Note: [Interpretation susceptibility to antibiotics: $\mathrm{R}=$ resistant, $\mathrm{I}=$ Intermediate, $\mathrm{S}=$ Sensitive]. Determination of interpretation according to standards described by Swenson et al. (1990) and Walker (2006): erythromycin ( $\mathrm{R}=\operatorname{diz} \leq 13 \mathrm{~mm}, \mathrm{I}=13 \mathrm{~mm}<\operatorname{diz}<23 \mathrm{~mm}, \mathrm{~S}=\operatorname{diz} \geq 23 \mathrm{~mm}$ ); chloramphenicol $(\mathrm{R}=\operatorname{diz} \leq 12 \mathrm{~mm}, \mathrm{I}=12 \mathrm{~mm}<\operatorname{diz}<18 \mathrm{~mm}, \mathrm{~S}=\operatorname{diz} \geq 18 \mathrm{~mm})$; tetracycline $(\mathrm{R}=\operatorname{diz} \leq 14 \mathrm{~mm}, \mathrm{I}=14 \mathrm{~mm}<\operatorname{diz}<18 \mathrm{~mm} \mathrm{~S}=\operatorname{diz} \geq 18 \mathrm{~mm}) ; \mathrm{bambermycin}$ $(\mathrm{R}=\operatorname{diz} \leq 15 \mathrm{~mm}, \mathrm{I}=15 \mathrm{~mm}<\operatorname{diz}<20 \mathrm{~mm}, \mathrm{~S}=\operatorname{diz} \geq 20 \mathrm{~mm}$ ).

biotics. Isolates E5, E7, and E8 were chosen to be tested to the next assay because they showed no resistant to antibiotics tested.

\section{Tolerance to Gastrointestinal $\mathrm{pH}$ and Bile Salt}

The result showed that each of $\mathrm{LAB}$ isolates had different survival abilities to different $\mathrm{pH}$ and bile salt conditions (Table 2 and Table 3). All LAB isolates had good survival ability at $\mathrm{pH} 7.2$ condition. E8 isolate could survive better than E5 and E7 isolates at pH 4 conditions. In contrast, E5 and E7 isolates had better surviv- al ability than E8 isolate at $\mathrm{pH} 3$ condition. Compared with previous study by Lin et al. (2007), the survival ability of E5, E7, and E8 isolates were better than $L$. fermentum which decreased about 2-3 Log CFU/mL at $\mathrm{pH} 3.2$ condition after $3 \mathrm{~h}$ incubation. The LAB isolates that were able to survive at low $\mathrm{pH}$ could be due to the physiological mechanisms that regulate intracellular $\mathrm{pH}$ homeostasis (Guchte et al., 2002). The viable cell of LAB isolates decreased significantly at $\mathrm{pH} 2$ conditions. This condition was similar with previous study by Anderson et al. (2010) reporting that L. plantarum DSM 2648 and L. rhamnosus HN001 were able to survive at $\mathrm{pH} 4$ but both

Table 2. The decrease in cell viability (Log CFU/mL) of LAB isolates in MRS broth with various $\mathrm{pH}$ ( $3 \mathrm{~h}$ incubation) and MRS broth $+0.5 \%(\mathrm{w} / \mathrm{v})$ bile salt ( $5 \mathrm{~h}$ incubation) at $37^{\circ} \mathrm{C}(\mathrm{n}=3)$

\begin{tabular}{cccccc}
\hline \multirow{2}{*}{ LAB Isolates } & \multicolumn{5}{c}{ Decrease in cell viability of LAB isolates (Log CFU/mL) } \\
\cline { 2 - 6 } & $\mathrm{pH} 2$ & $\mathrm{pH} \mathrm{3}$ & $\mathrm{pH}$ & $\mathrm{pH} \mathrm{7.2}$ & $0.5 \%$ Bile Salt \\
\hline E5 & $6.02 \pm 0.12^{\mathrm{b}}$ & $1.23 \pm 0.08^{\mathrm{a}}$ & $0.68 \pm 0.21^{\mathrm{ab}}$ & $0.47 \pm 0.03^{\mathrm{a}}$ & $0.47 \pm 0.09^{\mathrm{a}}$ \\
E7 & $6.69 \pm 0.10^{\mathrm{c}}$ & $1.35 \pm 0.13^{\mathrm{a}}$ & $1.04 \pm 0.25^{\mathrm{b}}$ & $0.33 \pm 0.37^{\mathrm{a}}$ & $0.40 \pm 0.07^{\mathrm{a}}$ \\
E8 & $5.80 \pm 0.04^{\mathrm{a}}$ & $1.67 \pm 0.08^{\mathrm{b}}$ & $0.29 \pm 0.24^{\mathrm{a}}$ & $0.12 \pm 0.07^{\mathrm{a}}$ & $0.64 \pm 0.07^{\mathrm{b}}$ \\
\hline
\end{tabular}

Note: Means in the same column with different superscripts differ significantly $(\mathrm{P}<0.05)$. 
Table 3. Survival rate (\%) of LAB isolates in MRS broth with various $\mathrm{pH}(3 \mathrm{~h}$ incubation) and MRS broth $+0.5 \%$ (w/v) bile salt $(5 \mathrm{~h}$ incubation) at $37^{\circ} \mathrm{C}(\mathrm{n}=3)$

\begin{tabular}{cccccc}
\hline \multirow{2}{*}{ LAB isolates } & \multicolumn{5}{c}{ Survival rate of LAB isolates (\%) } \\
\cline { 2 - 6 } & $\mathrm{pH} 2$ & $\mathrm{pH} \mathrm{3}$ & $\mathrm{pH} \mathrm{4}$ & $\mathrm{pH} \mathrm{7.2}$ & $0.5 \%$ bile salt \\
\hline E5 & $35.61 \pm 1.52^{\mathrm{b}}$ & $86.91 \pm 0.76^{\mathrm{b}}$ & $92.65 \pm 2.27^{\mathrm{ab}}$ & $94.90 \pm 0.38^{\mathrm{a}}$ & $94.60 \pm 0.95^{\mathrm{b}}$ \\
E7 & $31.24 \pm 2.34^{\mathrm{a}}$ & $86.11 \pm 1.12^{\mathrm{b}}$ & $88.88 \pm 2.74^{\mathrm{a}}$ & $96.52 \pm 3.99^{\mathrm{a}}$ & $95.20 \pm 0.88^{\mathrm{b}}$ \\
E8 & $41.15 \pm 0.19^{\mathrm{c}}$ & $83.01 \pm 0.73^{\mathrm{a}}$ & $96.67 \pm 2.72^{\mathrm{b}}$ & $98.63 \pm 0.80^{\mathrm{a}}$ & $92.73 \pm 0.76^{\mathrm{a}}$ \\
\hline
\end{tabular}

Note: Means in the same column with different superscripts differ significantly $(\mathrm{P}<0.05)$.

isolates decreased about 6-7 Log CFU/mL at $\mathrm{pH} 2$ condition. The survival ability of E8 isolate was better than E5 and E7 isolates at $\mathrm{pH} 2$ condition shown by survival rate was $41.15 \pm 0.19 \%$. Compared with previous study by Pan et al. (2009), survival ability of E8 isolate was better than L. acidophilus NIT, the survival rate of L. acidophilus NIT was zero after $2 \mathrm{~h}$ incubation at $\mathrm{pH} 2$ conditions. The decrease of viable cell of LAB isolates was caused by oxidizing cell by acid. Hydrochloric acid $(\mathrm{HCl})$ was secreted by stomach that can lead to oxidize cell components, damaging the membrane electron transport, decreased activity of various enzymes that are sensitive to acid (van de Guchte et al., 2002).

The observation of survival ability of LAB isolates to bile salt showed that the survival rate of all LAB isolates were above $90 \%$ (Table 2 and 3). These results were better than previous study by Lee et al. (2014) that reported survival rate of $P$. pentosaceus F66 was $26.6 \%$ at $0.3 \%$ bile salt condition after $2 \mathrm{~h}$ incubation and Jannah et al. (2014) reported that CCM011, CSP004, and CVM002 isolates could not grow at $0.3 \%$ bile salt condition after $5 \mathrm{~h}$ incubation. The LAB isolates are resistant to bile salts because of their ability to detoxify the conjugated bile acids into deconjugated bile acid by the activities of bile salt hydrolases (BSH). The conjugated bile acids have bactericidal effect against sensitive microorganisms (Begley et al., 2006).

\section{Antimicrobial Activity of LAB against Pathogenic Bacteria}

One of the major probiotic's properties is their inhibitory effect against the growth of pathogenic bacteria. In this study, untreatment supernatants (positive control) from all LAB isolates showed antimicrobial activity against $S$. enteritidis and E. casseliflavus (Table 4). The isolate of E8 showed the highest inhibitory effect against E. casseliflavus. These inhibitory effects could be due to the activity of organic acids (Makras \& De Vyust, 2006), bacteriocin or bacteriocin-like inhibitory substances and hydrogen peroxide (Klose et al., 2010) produced by LAB. The neutralized supernatants $(\mathrm{pH}$ 6.5) from all LAB isolates have no effects against $S$. enteritidis. This result indicated that the inhibitory activity was related to the organic acids produced by LAB. Untreatment supernatants $\mathrm{pH}$ was 4.36 in this study. Organic acids produced by LAB lead to bactericidal effect against Gram-positive and Gram-negative (Tejero-Sarinena et al., 2012). In contrast, inhibitory activity was non-activated against E. casseliflavus when the neutralized supernatants were added by proteinase. This result indicated that the organic acid is not the only inhibitory factor of $E$. casseliflavus growth but is partly due to the inhibitory activities of bacteriocin or bacteriocin-like inhibitory substances. Based on these results, we can conclude that bacteriocin or bacteriocin-like inhibitory substances produced by LAB isolates were not effective in inhibiting S. enteritidis growth. Todorov \& Dicks (2009) reported that bacteriocins from LAB species did not affect Gram-negative bacteria except few strains, however, effective to most of species closely related phylogenetic to the bacteriocin producer. Isolate of E8 had inhibitory activity of bacteriocin or bacteriocin-like inhibitory substances better than E5 and E7 isolates. Bacteriocin binds to non-specific receptors or specific receptor on the cell surface of Gram-positive sensitive, probably lipoteichoic acid layer. Ionic reaction between bacteriocins and cell membranes lead to membrane leakage and the release of the membrane components (Todorov \& Dicks, 2009).

\section{Ability of LAB Isolates to Adhere to Chicken Ileal Cell}

All LAB isolates could adhere to the ileal cells. These results were exhibited by the number of viable cell of LAB isolates were significantly $(\mathrm{P}<0.05)$ higher than control after $30 \mathrm{~min}$ incubation (Table 5). These

Table 4. Diameter inhibition zone (mm) of LAB supernatant against pathogenic bacteria

\begin{tabular}{|c|c|c|c|c|c|c|}
\hline \multirow[t]{2}{*}{ LAB isolates } & \multicolumn{2}{|c|}{$\begin{array}{l}\text { Untreatment supernatant } \\
\text { (positive control } \mathrm{pH} \pm 4.36\end{array}$} & \multicolumn{2}{|c|}{$\begin{array}{l}\text { Neutralized supernatant } \\
\text { (pH 6.5) }\end{array}$} & \multicolumn{2}{|c|}{$\begin{array}{l}\text { Neutralized supernatant (pH 6.5) } \\
\text { added by K-Proteinase } 1 \mathrm{mg} / \mathrm{mL}\end{array}$} \\
\hline & S. enteritidis & E. casseliflavus & S. enteritidis & E. casseliflavus & S. enteritidis & E. casseliflavus \\
\hline E5 & $12.75 \pm 0.50^{\mathrm{a}}$ & $18.75 \pm 0.50^{\mathrm{b}}$ & - & $16.50 \pm 0.58^{b}$ & - & - \\
\hline E7 & $16.00 \pm 0.82^{\mathrm{b}}$ & $16.50 \pm 0.57^{\mathrm{a}}$ & - & $14.50 \pm 1.00^{\mathrm{a}}$ & - & - \\
\hline E8 & $17.75 \pm 0.50^{c}$ & $19.75 \pm 0.95^{\mathrm{b}}$ & - & $17.75 \pm 0.96^{\mathrm{b}}$ & - & - \\
\hline
\end{tabular}

Note: Means in the same column with different superscripts differ significantly $(\mathrm{P}<0.05)$. ( - ) = no inhibition zone. 
Table 5. Ability of LAB isolates to adhere to ileal cells in PBS $\mathrm{pH}$ 7.2 for $30 \mathrm{~min}$

\begin{tabular}{ccc}
\hline $\begin{array}{c}\text { LAB } \\
\text { Isolates }\end{array}$ & $\begin{array}{c}\text { Number of viable bacterial adhere } \\
\text { to ileal cell }\left(\log \text { CFU/cm }{ }^{2}\right.\end{array}$ & $\begin{array}{c}\text { Adhesion } \\
(\%)\end{array}$ \\
\hline Control & $5.30 \pm 0.14^{\mathrm{a}}$ & - \\
E5 & $7.65 \pm 0.07^{\mathrm{b}}$ & $81.81 \pm 1.46^{\mathrm{a}}$ \\
E7 & $8.95 \pm 0.07^{\mathrm{c}}$ & $91.04 \pm 2.34^{\mathrm{b}}$ \\
E8 & $9.40 \pm 0.00^{\mathrm{d}}$ & $94.77 \pm 0.09^{\mathrm{b}}$ \\
\hline
\end{tabular}

Note: Means in the same column with different superscripts differ significantly $(\mathrm{P}<0.05)$

results also exhibited that each isolates had different adhesion abilities. The adhesion ability of E8 isolate was better than those of E5 and E7 isolates, which was indicated by the number of viable bacteria was $9.40 \pm 0.00$ $\mathrm{Log}$ CFU/ $\mathrm{cm}^{2}$ with adhesion cell was $94.77 \pm 0.09 \%$, while E5 isolate had adhesion ability that was too low i.e., $81.81 \pm 1.46 \%$. Babot et al. (2014) reported that two strains isolated from broiler's intestine had different adhesion abilities, L. reuteri LET 206 was able to adhere to chicken ileal cell as much as $43.3 \%$ while $L$. reuteri LET 211 was able to adhere to ileal cell as much as $37 \%$. The differences in adhesion abilities of strains are specific and depend on physiology of cell and composition of cell wall (Ranadheera et al., 2012). Adhesive activity was caused by the interaction between the multiple components of glycoproteins, lipid anchored proteins of the bacterial cell surface layer with specific receptor of molecules carbohydrate extracellular matrix layer of epithelial cells and intestinal mucus layer (Schillinger et al., 2005).

\section{Molecular Identification of 16S rRNA Gene of LAB Isolates}

Electrophoresis visualization showed that the DNA fragments of 16S rRNA gene amplification products of LAB isolates E5, E7, and E8 were \pm 1500 bp (Fig 1a). The BLAST-N result showed that sequences alignment of three isolates of LAB (isolate E5, E7, and E8) had 99\% similarity with Pediococcus pentosaceus ATCC 25745 strain. The phylogenetic dendrogram showed that isolates E5, E7, and E8 were clustered in a group and they were closely related with $P$. pentosaceus (Fig $1 b$ ).

\section{CONCLUSION}

LAB isolates E5, E7, and E8 were sensitive to antibiotics, able to survive to gastrointestinal $\mathrm{pH}$ and $0.5 \%$ bile salt, able to produce antimicrobial activity such as organic acids and bacteriocin-like inhibitory substances, and able to adhere to chicken ileal cell in in vitro. E8 isolate had a better potential compared to E5 and E7 isolates in most in vitro assay as a candidate probiotics. E5, E7, and E8 isolates had 99\% similarity with Pediococcus pentosaceus ATCC 25745 strain.

\section{ACKNOWLEDGEMENT}

This research was supported by the academic scholarship from Directorate General of Higher
Education, Ministry of Education and Culture, Republic of Indonesia, and BOPTN 2013 awarded to Anja Meryandini.

\section{REFERENCES}

Anderson, R. C., A. L. Cookson, W. C. McNabb, W. J. Kelly, \& N. C. Roy. 2010. Lactobacillus plantarum DSM2648 is a potential probiotic that enhances intestinal barrier function. FEMS Microbiol Lett. 309:184-192. http://dx.doi. org/10.1111/j.1574-6968.2010.02038.x

Babot, J. D., E. Arganaz-Martinez, L. Saavedra, M. C. Apella, \& A. P. Chaia. 2014. Selection of indigenous lactic acid bacteria to reinforce the intestinal microbiota of newly hatched chicken - relevance of in vitro and ex vivo methods for strains characterization. Res. Vet. Sci. 97:8-17. http://dx.doi. org/10.1016/j.rvsc.2014.06.001

Bao, Y., Y. Zhang, Y. Zhang, Y. Liu, S. Wang, X. Dong, Y. Wang, \& H. Zhang. 2010. Screening of potential probiotic properties of Lactobacillus fermentum isolated from traditional dairy products. Food. Contr. 21:695-701. http://dx.doi. org/10.1016/j.foodcont.2009.10.010

Begley, M., C. Hill, \& C. G. M. Gahan. 2006. Bile salt hydrolase activity in probiotics. Appl. Environ. Microbiol. 73:17291738.

Castanon, J. I. R. 2007. History of the use of antibiotic as growth promoters in European poultry feeds. Poult. Sci. 86:24662471. http://dx.doi.org/10.3382/ps.2007-00249

EFSA. 2012. Guidance on the assessment of bacterial susceptibility to antimicrobials of human and veterinary importance. EFSA Panel on Additives and Products or Substances used in Animal Feed (FEEDAP). EFSA Journal. 2740:1-10.

FAO/WHO (Food and Agriculture Organization of the United Nations \& World Health Organization). 2002. Guidelines for evaluation of probiotic in food. Report of Joint FAO/ WHO Working Group on drafting Guidelines for the evaluation of probiotic in food. London Ontario, Canada.

Felsenstein, J. 1985. Confidence limits on phylogenies: an approach using the bootstrap. Evolution. 39: 783-791. http:// dx.doi.org $/ 10.2307 / 2408678$

Gunal, M., G. Yayli, O. Kaya, N. Karahan, \& O. Sulak. 2006. The effects of antibiotic growth promoter, probiotic or organic acid supplementation on performance, intestinal microflora and tissue of broilers. Int. J. Poult. Sci. 5:149-155. http://dx.doi.org/10.3923/ijps.2006.149.155

Huyghebaert, G., R. Ducatelle, \& F. V. Immerseel. 2011. An update on alternatives to antimicrobial growth promoters for broilers. Vet. J. 187:182-188. http://dx.doi.org/10.1016/j. tvj1.2010.03.003

Jannah, SN., A. Dinoto, K. G. Wiryawan, \& I. Rusmana. 2014. Characteristic of lactic acid bacteria isolated from gastrointestinal tract cemani chicken and their potential use as probiotics. Med. Pet. 37:182-189. http://dx.doi.org/10.5398/ medpet.2014.37.3.182

Jeong, S. H., Y. K. Song, \& J. H. Cho. 2009. Risk assessment of ciprofloxacin, flavomycin, olaquindox and colistin sulfate based on microbiological impact on human gut biota. Regulat. Toxicol. Pharmacol. 53:209-216. http://dx.doi. org/10.1016/j.yrtph.2009.01.004

Kementrian Pertanian. 2009. Peraturan Menteri Pertanian Republik Indonesia Nomor 18 Tahun 2009 tentang Peternakan dan Kesehatan Hewan. Kementan, Indonesia.

Klare, I., C. Konstabel, G. Werner, H. Geert, V. Vankerckhoven, G. Kahlmeter, B. Hildebrandt, S. Muller-Bertling, W. Witte, \& H. Goossens. 2007. Antimicrobial susceptibilities of Lactobacillus, Pediococcus and Lactococcus human isolates and cultures intended for probiotic or nutritional use. J. Antimicrob. Chemother. 59:900-912. http://dx.doi. org/10.1093/jac/dkm035 
Klose, V., K. Bayer, R. Bruckbeck, \& G. Schatzmayr. 2010. In vitro antagonistic activities of animal intestinal strains against swine - associated pathogens. Vet. Microbiol. 144:515-521. http://dx.doi.org/10.1016/j.vetmic.2010.02.025

Lee, K. W., J. Y. Park, H. D. Sa, J. H. Jeong, D. E. Jin, J. J. Heo, \& J. H. Kim. 2014. Probiotic properties of Pediococcus strains isolated from jeotgals, salted and fermented Korean seafood. Anaerobe. 28:199-206. http://dx.doi.org/10.1016/j.anaerobe.2014.06.013

Lin, W. H., B. Yu, S. H. Jang, \& H. Y. Tsen. 2007. Different probiotic properties for Lactobacillus fermentum strains isolated from swine and poultry. Anaerobe. 13:107-113. http:// dx.doi.org/10.1016/j.anaerobe.2007.04.006

Makras, L., \& L. De Vuyst. 2006. The in vitro inhibition of Gramnegative pathogenic bacteria by bifidobacteria is caused by the production of organic acids. Int. Dairy. J. 16:1049-1057. http://dx.doi.org/10.1016/j.idairyj.2005.09.006

Marchesi, J. R., T. Sato, A. J. Weightman, T. A. Martin, J. C. Fry, S. J. Hiom, D. Dymock, \& W. G. Wade. 1998. Design and evaluation of useful bacterium-specific PCR primer that amplify genes coding for bacterial $16 \mathrm{~S}$ rRNA. Appl Environ. Microbiol. 64:795-799.

Mayra-Makinen, A., M. Manninen, \& H. Gyllenberg. 1983. The adherence of lactic acid bacteria to the columnar epithelial cells of pigs and calves. J. Appl. Bacteriol. 55:241245. http://dx.doi.org/10.1111/j.1365-2672.1983.tb01321.x

Messaoudi, S., A. Madi, H. Prevost, M. Feuilloley, M. Manai, X. Dousset, \& N. Connil. 2012. In vitro evaluation of the probiotic potential of Lactobacillus salivarus SMXD51. Anaerobe. 18:584-589. http://dx.doi.org/10.1016/j.anaerobe.2012.10.004

Nawaz, M., J. Wang, A. Zhou, C. Ma, X. Wu, J. E. Moore, B. C. Millar, \& J. Xu. 2011. Characterization and transfer of antibiotic resistance in lactic acid bacteria from fermented food products. Curr. Microbiol. 62:1081-1089. http://dx.doi. org/10.1007/s00284-010-9856-2

Ouoba, L. I. I., V. Lei, \& L. B. Jensen. 2008. Resistance of potential probiotic lactic acid bacteria and bifidobacteria of African and European origin to antimicrobials: Determination and transferability of the resistance genes to other bacteria. Int. J. Food. Microbiol. 121:217-224. http://dx.doi. org/10.1016/j.ijfoodmicro.2007.11.018

Pan, X., F. Chen, T. Wu, H. Tang, \& Z. Zhao. 2009. The acid, bile tolerance and antimicrobial property of Lactobacillus acidophilus NIT. Food Cont. 20:598-602.

Pfaller, M. A. 2006. Flavophospholipol use in animals: positive implications for antimicrobial resistance based on its microbiologic properties. Diagnos. Microbiol. Infec. Diseases. 56:115-121. http://dx.doi.org/10.1016/j.diagmicrobio.2006.03.014

Ranadheera, C. S., C. A. Evans, M. C. Adams, \& S. K. Baines. 2012. In vitro analysis of gastrointestinal tolerance and intestinal cell adhesion of probiotics in goat's milk ice cream and yogurt. Food. Res. Int. 49:619-625. http://dx.doi. org/10.1016/j.foodres.2012.09.007
Rosyidah, E., A. Meryandini, \& T. C. Sunarti. 2013. The use of lactic acid bacteria and cellulolytic bacteria to improve the chemical properties of corn flour. Makara. J. Sci. 17:75-80. http://dx.doi.org/10.7454/mss.v17i3.2944

Schillinger, U., C. Guigas, \& W. H. Holzapfel. 2005. In vitro adherence and other properties of lactobacilli used in probiotic yoghurt-like products. Int. Dairy. J. 15:1289-1297. http://dx.doi.org/10.1016/j.idairyj.2004.12.008

Swenson, J. M., R. R. Facklam, \& C. Thornsberry. 1990. Antimicrobial susceptibility of vancomycin-resistant Leuconostoc, Pediococcus, and Lactobacillus species. Antimicrob. Agents. Chemother. 34:543-549. http://dx.doi.org/10.1128/ AAC.34.4.543

Tao, Y., G. Yu, D. Chen, Y. Pan, Z. Liu, H. Wei, D. Peng, L. Huang, Y. Wang, \& Z. Yuan. 2012. Determination of 17 macrolide antibiotics and avermectins residues in meat with accelerated solvent extraction by liquid chromatography-tandem-mass spectrometry. J. Chrom. B. 897:64-71. http://dx.doi.org/10.1016/j.jchromb.2012.04.011

Tejero-Sarinena, S., J. Barlow, A. Costabile, G. R. Gibson, \& I. Rowland. 2012. In vitro evaluation of the antimicrobial activity of a range of probiotics against pathogens: Evidence for the effects of organic acids. Anaerobe. 18:530-538. http://dx.doi.org/10.1016/j.anaerobe.2012.08.004

Thumu, S.C., \& P. M. Halami. 2012. Presence of erythromycin and tetracycline resistance genes in lactic acid bacteria from fermented foods of Indian origin. Antonie van Leeuwenhoek. 102:541-551. http://dx.doi.org/10.1007/s10482012-9749-4

Todorov, S. D., \& L. M. T. Dicks. 2009. Bacteriocin production by Pediococcus pentosaceus isolated from marula (Screrocarya birrea). Int. J. Food. Microbiol. 132:117-126. http:// dx.doi.org/10.1016/j.ijfoodmicro.2009.04.010

Van de Guchte, M., P. Serror, C. Chervaux, T. Smokvina, S. D. Emrlich, \& M. Marguin. 2002. Stress responses in lactic acid bacteria. Antonie van Leeuwenhoek. 82:187-216. http://dx.doi.org/10.1023/A:1020631532202

Vignaroli, C., S. Pasquaroli, G. Zandri, L. Aquilanti, \& F. Biavasco. 2011. Multidrug-Resistant Enterococci in Animal Meat and Faeces and Co-Transfer of Resistance from an Enterococcus durans to a Human Enterococcus faecium. Curr. Microbiol. 62:1438-1447. http://dx.doi.org/10.1007/s00284011-9880-x

Walker, R. D. 2006. Antimicrobial Susceptibility Testing Methods and Interpretation of Results. In: S. Giguere, J. F. Prescott, J. D. Baggot, R. D. Walker, \& P. M. Dowling (Eds). Antimicrobial Therapy in Veterinary Medicine. $4^{\text {th }}$ Edition. Blackwell Publishing, Australia. p. 11-25.

Wiryawan, K. G., S. Suharti, \& M. Bintang. 2005. Kajian antibakteri temulawak, jahe dan bawang putih terhadap Salmonella typhimuriam serta pengaruh bawang putih terhadap performans dan respon imun ayam pedaging. Med. Pet. 28: 52-62. 